\title{
Survey of Mycotoxin in Brazilian Corn by NIR Spectroscopy-Year 2019
}

\author{
Carlos Augusto Mallmann ${ }^{1 *}$, Adriano Olnei Mallmann ${ }^{2}$ and Denize Tyska ${ }^{1}$ \\ ${ }^{1}$ Department of Preventive Veterinary Medicine, Federal University of Santa Maria, Brazil \\ ${ }^{2}$ Pegasus Science, Santa Maria, Rio Grande do Sul, Brazil
}

*Corresponding author: Igor Fernandes, Phytoalgae and University of Madeira, Funchal, Portugal.

Received Date: June 08, 2020

Published Date: July 07, 2020

\begin{abstract}
Corn is commonly attacked by fungi and mycotoxins. The negative impacts caused by these toxic metabolites justify the use tools that enable constant monitoring and provide a quick feedback. The natural occurrence of mycotoxins, fumonisins B1+B2 (FUM), Aflatoxin B1 (AFB1), Deoxynivalenol (DON) and Zearalenone (ZEN) was investigated through Near Infrared Spectroscopy (NIR) in 3,069 spectra of corn samples from several Brazilian states throughout 2019. FUM was the most prevalent (98.2\%) mycotoxin found in this study, followed by AFB1 (20.3\%), DON $(9.6 \%)$ and ZEN (5.9\%). The annual average of FUM (B1+B2) was $2,092 \mu \mathrm{g} \mathrm{kg}^{-1}$ and the average in positive samples was 2,130 $\mu \mathrm{g} \mathrm{kg}{ }^{-1}$, with variations in some periods of the year. The annual mean of AFB1 was low, $1.8 \mu \mathrm{g} \mathrm{kg}^{-1}$, and the average in positive samples was $8.9 \mu \mathrm{g} \mathrm{kg}$. As well as the prevalence, the concentrations of DON and ZEN were relatively low: 39 and $6 \mu \mathrm{g} \mathrm{kg}^{-1}$, respectively. These findings show the importance of mycotoxicological monitoring to avoid economic losses and to spare animal health. The use of rapid diagnostic tools, such as NIR, allows decision making in an agile and efficient way.
\end{abstract}

Keywords: Zea mays L; Aflatoxins; Fumonisins; Online; Monitoring; Risk

\section{Introduction}

Corn (Zea mays L.) is one of the most cultivated cereals around the world. It has a relevant role in economy and society due to its high nutritional value and productive potential [1,2]. Brazil is the third major producer of corn, after the United States and China [3]. Most Brazilian states are corn producers, but the largest volume of the cereal is harvested in the mid-west, the southeast and the south regions. Considering the 2018/2019 corn harvest, the leading state was Mato Grosso (31.3\%), followed by Paraná (16.7\%) and Goiás (11.5\%) [4]. The main destination of this commodity is the domestic market, with the animal feed sector being its largest consumer [5].

Brazilian climatic conditions in association with harvest, storage and transport issues, can cause fungal growth and mycotoxin production [6-8]. Corn is widely attacked by fungi and mycotoxins because it is a highly nutritious substrate for their development [9-11]. The main mycotoxins found in Brazilian corn are those of the Aspergillus genus that produce aflatoxins (AFBs), and those of the Fusarium genus which produce fumonisins (FUM), zearalenone (ZEN) and deoxynivalenol (DON) [12,13]. Several studies have investigated these toxic substances due to their global economic impacts and toxic effects in humans and animals [14].

Mycotoxins can cause several deleterious health effects, mainly due to their anabolic, estrogenic, carcinogenic, mutagenic and teratogenic properties [15]. There are approximately two dozen known FUM; however, FB1, FB2 and FB3 stand out for their toxic effects in humans and animals [16,17]. FB1 is the most toxic and abundant of them all, representing about $70 \%$ of 
the total concentration of FUM in naturally contaminated food and raw materials, followed by FB2 and FB3 [18]. In horses, FUM cause hemorrhagic-liquefactive brain lesions (equine leuko encephalomalacia) [19], while in swine they trigger pulmonary edema [20]. In humans, these toxins are associated with eso phageal cancer [21,22].

AFBs (AFB1, AFB2, AFG1 and AFG2) are currently the most important mycotoxins [23] for inducing a drop in animal performance, in addition to their carcinogenic, teratogenic, hepatotoxic and immunosuppressive risk [24,25]. As a result, AFB1 was classified in class 1 of human carcinogens by International Agency for Research on Cancer (IARC) [26]. ZEN and its biotransformation products are well known for their impact on reproduction parameters, especially in sows [27,28]. Growing animals may show flaws in reproductive parameters and decreased semen quality [29]. DON is associated with digestive problems, causing vomiting, refusal to eat and lesions in the gastrointestinal tract, as well as interference with zootechnical parameters $[30,31]$.

Due to their negative impacts, monitoring of these toxic substances must be continuous. There are several sensitive, specific and reliable analytical methods used in the detection of mycotoxins in feed and food, such as Liquid Chromatography coupled to mass spectrometry (LC-MS/MS) and enzyme-linked immunosorbent assays (ELISA) [32,33]. Currently, optical methods, such as Near
Infrared Spectroscopy (NIR) [34,35], have made great headway for being agile and non-destructive technologies [34]. In view of the above, the present investigation aimed to assess the prevalence and average of mycotoxins in Brazilian corn through NIR prediction along 2019.

\section{Materials and Methods}

Three thousand and sixty-nine corn samples from ten states of Brazil were predicted throughout 2019. The spectra originated from routine samples predicted through the Olimpo platform, a web service of Pegasus Science Lt da [36], connected to different NIR equipment located in various Brazilian laboratories and industries. The samples were previously ground in a sampler miller with a sieve size of $1 \mathrm{~mm}$, homogenized and then read on the NIR equipment.

Subsequently, the corn samples were predicted for the presence and concentration of FUM (B1 and B2), AFB1, DON and ZEN. These assessments resulted in 6,134 predictions of FUM (B1 and B2), 3,069 of AFB1, 3,029 of DON and 2,971 of ZEN, amounting to 15,203 analyses. The LOQ (in $\mu \mathrm{g} \mathrm{kg}^{-1}$ ) for FB1, FB2, AFB1, DON and ZEN were 200, 200, 5, 350 and 30, respectively. The statistical evaluations were carried out by applying descriptive statistics (mean, range and prevalence) using the Stat graphics ${ }^{\circledR}$ Centurion XV software (Statgraphics Centurion 15.2.11, Manugistics Inc., Rockville, MD).

\section{Results and Discussion}

\section{Fumonisins B1+B2 (FUM)}

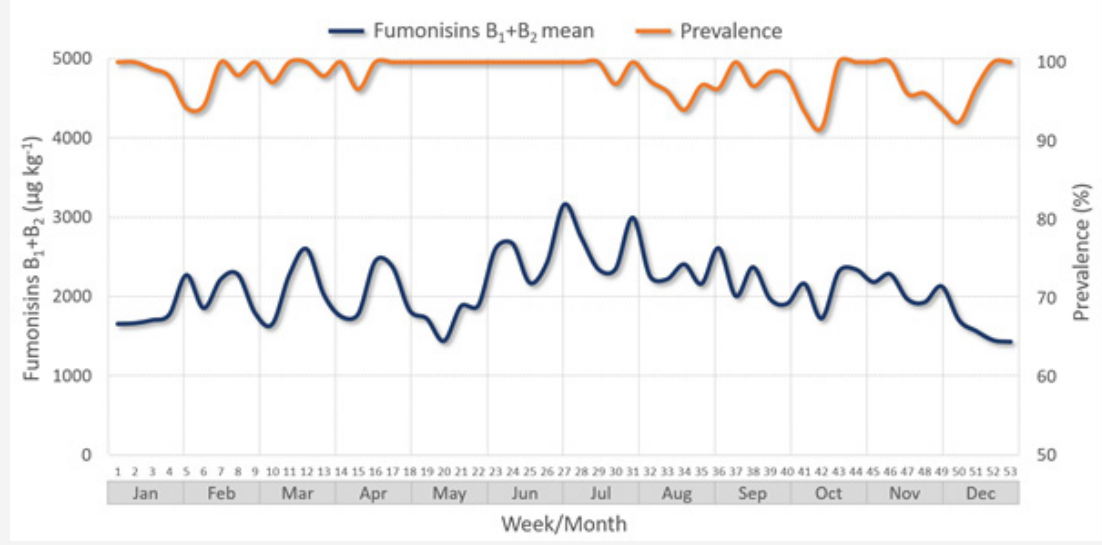

Figure 1: Weekly average concentration and prevalence of fumonisins in Brazilian samples of corn obtained via Near Infrared Spectroscopy in 2019.

The most prevalent mycotoxin was FUM, being detected in $98.2 \%$ of the samples. Its annual average was $2,092 \mu \mathrm{g} \mathrm{kg}^{-1}$, and the average in positive samples was $2,130 \mu \mathrm{g} \mathrm{kg}^{-1}$. FUM levels were slightly lower in May and December, around 1,700 $\mathrm{gg} \mathrm{kg}^{-1}$, when compared to June and July, around 3,000 $\mu \mathrm{g} \mathrm{kg}^{-1}$ (Figure 1).

In Goiás and Rio Grande do Sul states, the highest average concentrations were identified in the positive samples: 2,950 and $2,898 \mu \mathrm{g} \mathrm{kg}^{-1}$ in 69 and 691 samples, respectively (Figure 2).
The climate in Brazil is particularly favorable to the development of fungi of the Fusarium genus, which grow and produce FUM still in the field, with its high prevalence known from previous years $[37,38]$. FUM have received constant attention from researchers and Brazilian agribusiness; although not as toxic as AFBs, they have a higher prevalence in corn. Several studies have reported 90-100\% prevalence of FUM in Brazilian raw corn [39-42]. The present data show that more than $90 \%$ of the Brazilian corn was contaminated 
by FUM in 2019. Nonetheless, variations in concentration levels were observed throughout the year.

\section{Aflatoxin B1 (AFB1)}

The second most incident mycotoxin was AFB1, being detected in $20.3 \%$ of the samples. The mean AFB1 concentration and its weekly prevalence are shown in Figure 3. The annual mean was $1.8 \mu \mathrm{g} \mathrm{kg}^{-1}$, and the average in positive samples was $8.9 \mu \mathrm{g} \mathrm{kg}^{-1}$. The prevalence was slightly lower in winter (from June 21 to September $23)$, but the average concentration did not decrease significantly (Figure 3).

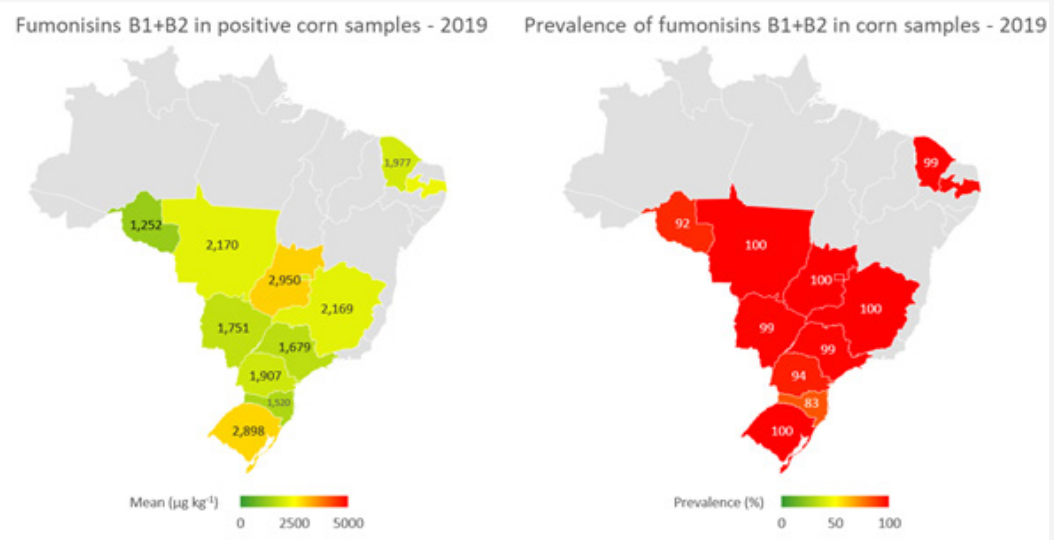

Figure 2: Average concentration in positive samples and prevalence of fumonisins in Brazilian samples of corn in 2019.

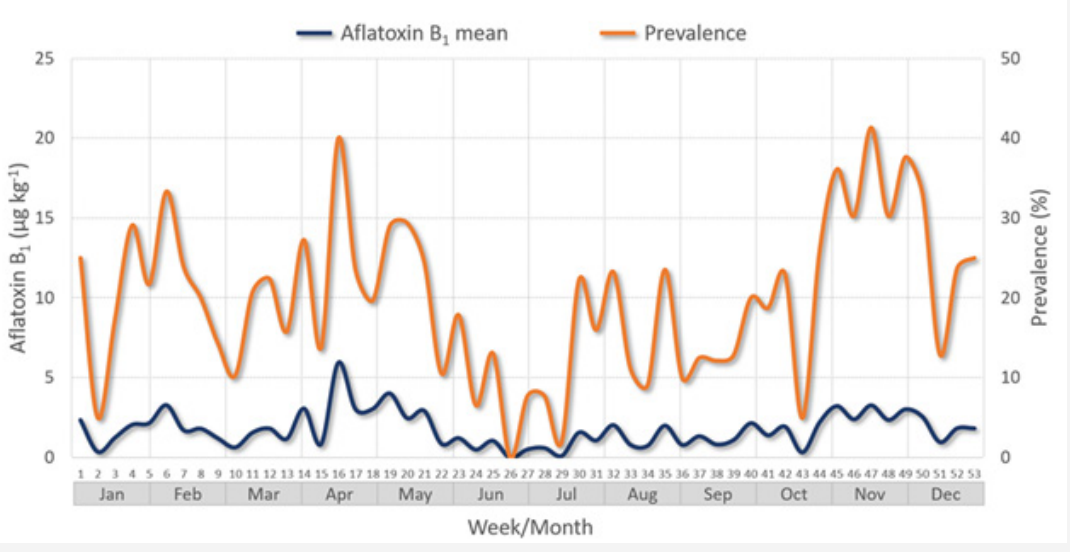

Figure 3: Weekly average concentration and prevalence of aflatoxin B1 in Brazilian samples of corn obtained via Near Infrared Spectroscopy in 2019.
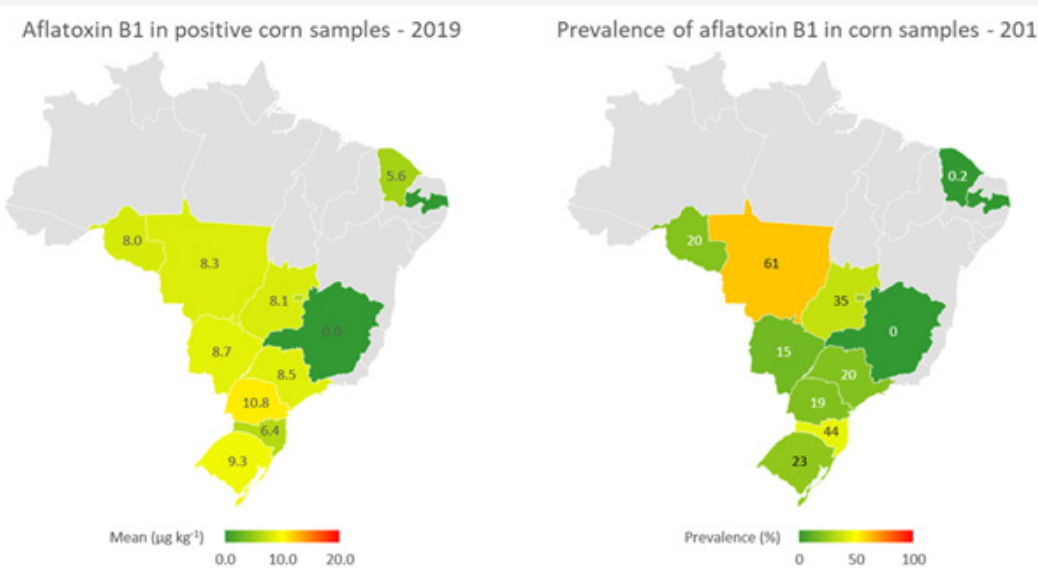

Figure 4: Average concentration in positive samples and prevalence of aflatoxin B1 in Brazilian samples of corn in 2019. 
Figure 4 illustrates the average concentration in positive samples with different origin by state and their respective prevalence. The highest prevalence was detected in Mato Grosso state: 263 samples had a positivity of $61.4 \%$ with average and positive mean of 5.1 and $8.3 \mu \mathrm{g} \mathrm{kg}^{-1}$, respectively. The prevalence of AFB1 was inconstant in 2019 , with occasional occurrence in the samples of some clients for a few weeks (Figure 4).

The current results are in agreement with earlier reports for Brazilian corn and corn-based products, in which a low frequency of aflatoxin contamination was detected [43-46]. So, this mycotoxin has historically had a low prevalence. AFB1 is produced by fungi of the Aspergillus genus, which has the characteristic of producing the toxin in the grains during the physiological maturation phase [47], harvest, transport, pre-cleaning, drying and storage, when the conditions of humidity, temperature and oxygen concentration are favorable (24). Infrastructure and care during the storaging stage have significantly improved in Brazil, which has caused aflatoxin levels to drop dramatically in the past two decades.

\section{Deoxynivalenol (DON)}

DON was detected in $9.6 \%$ of the samples, being the third most common mycotoxin in this survey. Its annual average was $39 \mu \mathrm{g} \mathrm{kg}^{-1}$, and the average in positive samples was $411 \mu \mathrm{g} \mathrm{kg}^{-1}$. In some weeks of September and December, the concentration was greater than $100 \mu \mathrm{g} \mathrm{kg}^{-1}$, and there was a prevalence of $20 \%$ (Figure 5).

The highest prevalence was identified in the Federal District and in Santa Catarina state: 75 and 61\% in 4 and 20 samples, respectively. The average concentration in all samples of these two states was 310 and $238 \mu \mathrm{g} \mathrm{kg}^{-1}$, respectively (Figure 6).

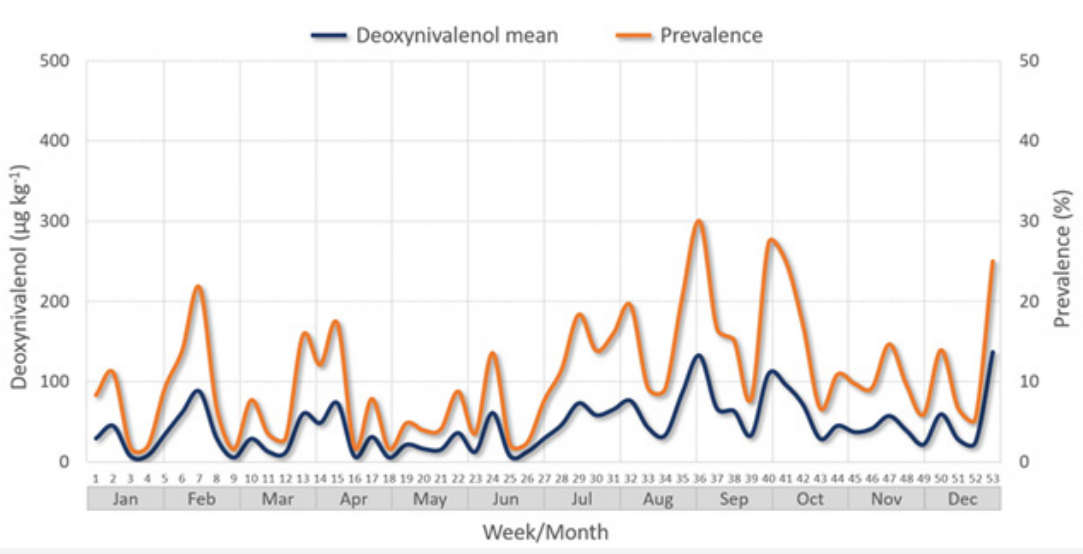

Figure 5: Weekly average concentration and prevalence of deoxynivalenol in Brazilian samples of corn obtained via Near Infrared Spectroscopy in 2019 .

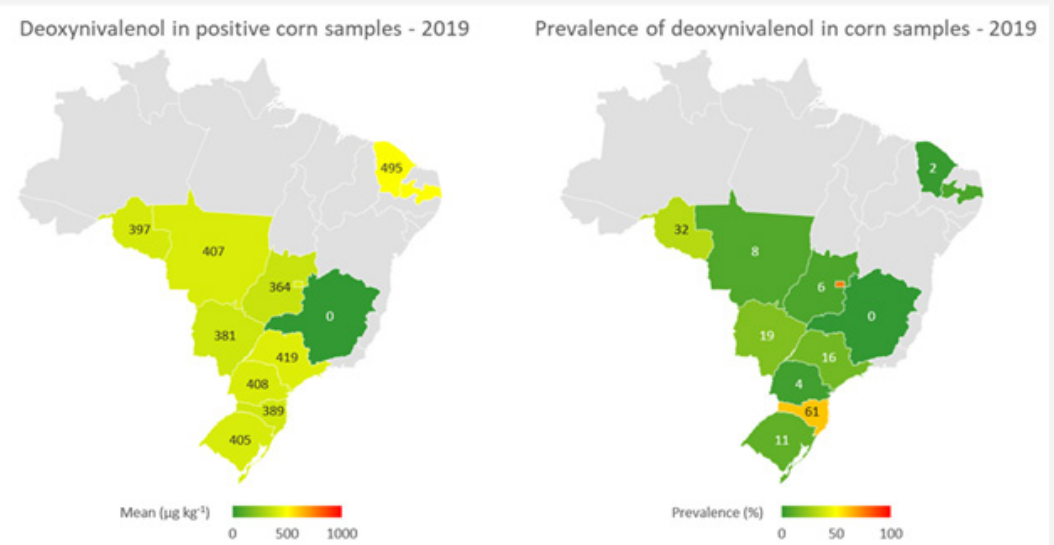

Figure 6: Average concentration in positive samples and prevalence of deoxynivalenol in Brazilian samples of corn in 2019.

The low prevalence, ranging from 0 to $20 \%$ in more than $90 \%$ of the weeks of 2019, is normal for Brazilian corn; according to several studies, DON does not usually affect this cereal at concentrations above $1000 \mu \mathrm{g} \mathrm{kg}^{-1}[46,48]$. A higher prevalence was occasionally identified in certain weeks in the samples of some clients. Reports using quantification limits below $350 \mu \mathrm{g} \mathrm{kg}^{-1}$ have shown a higher prevalence of DON, unlike other institutions that use official methodologies in which the prevalence of DON in Brazilian corn is generally in the range of $10 \%$ [49].

The toxic effects of DON in animals are related to digestive disorders and immunosuppression, thus justifying its monitoring and control. However, the greatest risk of DON occurrence is in 
Brazilian winter cereals such as wheat, barley and its derivatives [50].

\section{Zearalenone (ZEN)}

The annual mean of ZEN and the average in positive samples were 6 and $58 \mu \mathrm{g} \mathrm{kg}^{-1}$, respectively, so it was the least prevalent mycotoxin in this survey (5.9\%). Its prevalence was greater than $20 \%$ in some weeks of January and August. The highest average concentration was in the week between June and July (Figure 7).

In Rondônia, Mato Grosso and Santa Catarina states, 28, 263 and 20 samples were analyzed, respectively; no concentration of
ZEN above $30 \mu \mathrm{g} \mathrm{kg}^{-1}$ was identified. Minas Gerais state had a higher prevalence (33\%), but only 6 samples were analyzed (Figure 8).The prevalence of ZEN may be associated with colder climate conditions, as fungi producing ZEN grow at higher temperatures but need oscillations with mild temperatures to activate their secondary metabolism and produce the toxin [51,52]. Historically, ZEN has a higher prevalence in Brazilian corn, ranging from 20 to 30\%; however, a lower prevalence was observed in 2019. Toxicologically, ZEN is especially important in pigs and cattle; its occurrence is often associated with reproductive disorders in these species [53,54], so its monitoring is required.

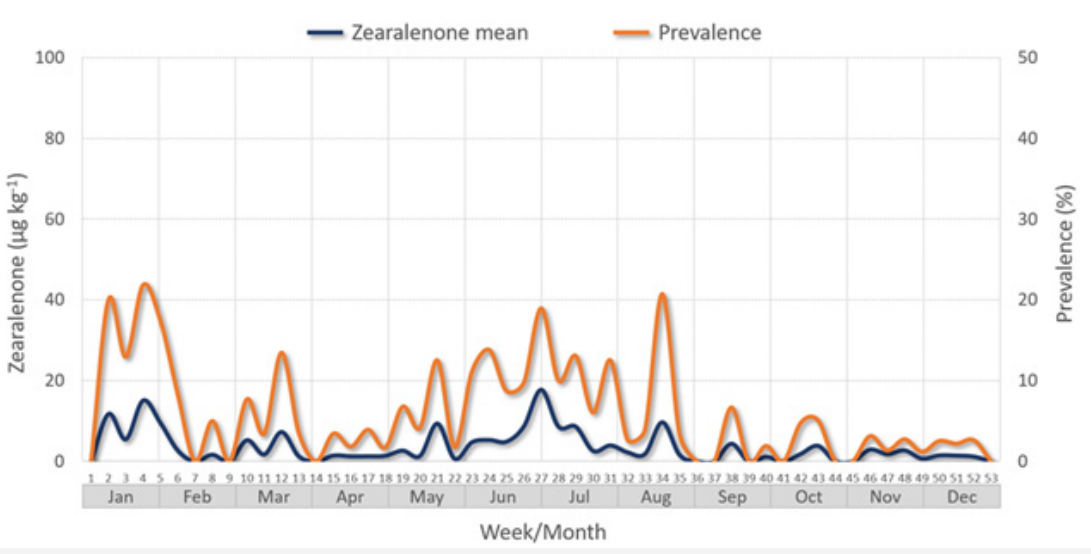

Figure 7: Weekly average concentration and prevalence of zearalenone in Brazilian samples of corn obtained via Near Infrared Spectroscopy in 2019.
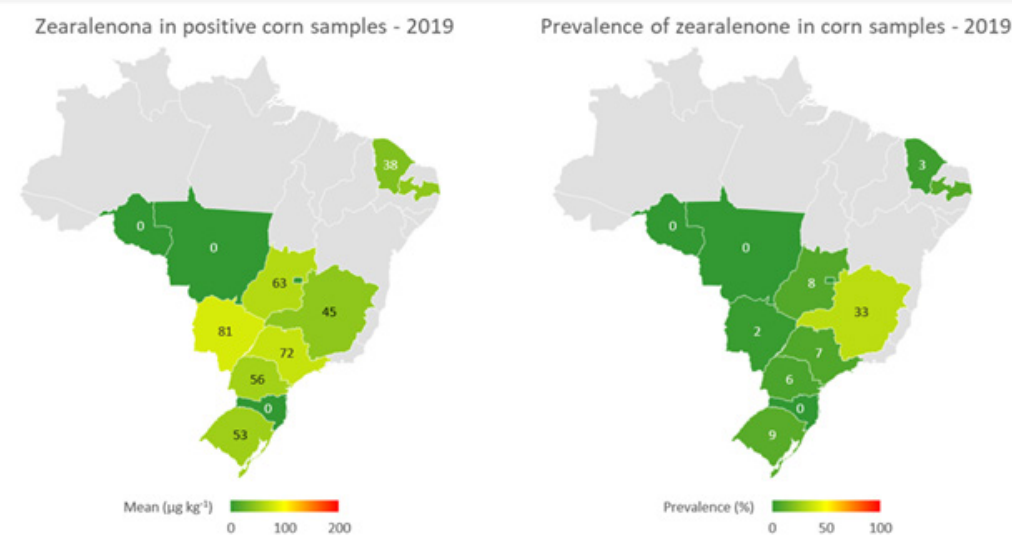

Figure 8: Average concentration in positive samples and prevalence of zearalenone in Brazilian samples of corn in 2019.

\section{Conclusion}

Mycotoxins' monitoring in corn must be permanent, as heterogeneity of the concentration may vary widely among batches of grains. The use of NIR to predict mycotoxins allows for a quick feedback, and a larger and more frequent amount of analyses may be performed, ensuring greater safety in the use of the cereal in animal and human nutrition.

The most important and prevalent mycotoxins in Brazilian corn presented different profiles of occurrence in 2019. The main findings of the present survey were the high prevalence of FUM, the fluctuating prevalence of AFB1, the point prevalence of DON, and the low prevalence of ZEN. The risk that each mycotoxin offers to the production system can be measured through continuous monitoring of the raw materials used in feed and food production. Besides the average concentration and prevalence of the mycotoxins, aspects related to each animal species such as sensitivity to a given mycotoxin, age and sex, as well as environmental, sanitary, genetic and nutritional factors, must be taken into account. 


\section{Acknowledgement}

None.

\section{Conflicts of Interest}

No conflict of interest.

\section{References}

1. Rouf TR, Prasad K, Kumar P (2016) Maize-A potential source of human nutrition and health: A review. Cogent Food And Agriculture 2(1).

2. Cowieson AJ (2005) Factors that affect the nutritional value of maize for broilers. Animal Feed Science and Technology 119(3-4): 293-305.

3. Ranum P, Pena Rosas J, Garcia Casal MN (2014) Global maize production utilization, and consumption. Ann N Y Acad Sci 1312: 105-112.

4. CONAB (2020) Acompanhamento da safra Brasileira Grãos. p. 114.

5. Abimilho (2020) Associação Brasileira das Indústrias de Milho [Internet].

6. Paterson R, Nelson Lima (2010) How climate change affects mycotoxins in food? Food Research International 43(7): 1902-1914.

7. Milani J (2013) Ecological conditions affecting mycotoxin production in cereals: A review. Vet Med (Praha) 58: 405-411.

8. Taniwaki MH, Pitt JI, Copetti MV, Teixeira AA, Iamanaka BT (2019) Understanding Mycotoxin Contamination Across the Food Chain in Brazil: Challenges and Opportunities. Toxins (Basel) 11(7): 411.

9. Sun XD, Su P, Shan H (2017) Mycotoxin Contamination of Maize in China. Comprehensive Reviews in Food Science and Food Safety 16(5): 835849.

10. Ferrigo D, Raiola A, Causin R (2014) Plant stress and mycotoxin accumulation in maize. Agrochim Pisa LVII:116-127.

11. Munkvold GP, Arias S, Taschl I, Gruber Dorninger (2019) Chapter 9 - Mycotoxins in Corn: Occurrence, Impacts, and Management. AACC International Press p. 235-287.

12. Alshannaq A, Yu JH (2017) Occurrence, Toxicity, and Analysis of Major Mycotoxins in Food. Int J Environ Res Public Health 14(6): 632.

13. Giorni P, Bertuzzi T, Battilani P (2019) Impact of Fungi Co-occurrence on Mycotoxin Contamination in Maize During the Growing Season. Front Microbiol 10: 1265.

14. Enyiukwu D, Awurum AN, Nwaneri JA (2014) Mycotoxins in stored agricultural products: implications to food safety and health and prospects of plant-derived pesticides as novel approach to their management. Greener J Microbiol Antimicrob 2: 32-48.

15. Omotayo OP, Omotayo AO, Mwanza M, Babalola 00 (2019) Prevalence of Mycotoxins and Their Consequences on Human Health. Toxicol Res 35(1): 1-7.

16. Pereira KC, Santos CF (2011) Micotoxinas e seu potencial carcinogênico Ensaios e Ciência Ciências Biológicas, Agrárias e Saúde 15(4): 19.

17. Reyes W, Anguiano Sevilla C, Anguiano Estrella R, Jiménez Ortega L Torres Morán P, et al. (2018) Niveles de fumonisinas en rastrojo de maíz para consumo equino en el estado de Jalisco. Rev Mex Ciencias Pecu 9: 846-854.

18. Scussel VM, Savi GD, Costas LLF, Xavier JJM, Manfio D, et al. (2014) Fumonisins in corn (Zea mays L.) from Southern Brazil. Food Addit Contam Part B Surveill 7(2): 151-155.

19. Marasas WF, Kellerman TS, Gelderblom WC, Coetzer JA, Thiel PG, et al. (1988) Leukoencephalomalacia in a horse induced by fumonisin B1 isolated from Fusarium moniliforme. Onderstepoort J Vet Res 55(4): 197-203.

20. Ross PF, Nelson PE, Richard JL, Osweiler GD, Rice LG, et al. (1990) Production of fumonisins by Fusarium moniliforme and Fusarium proliferatum isolates associated with equine leukoencephalomalacia and a pulmonary edema syndrome in swine. Appl Environ Microbiol 56(10): 3225-3226.

21. Myburg RB, Dutton MF, Chuturgoon AA (2002) Cytotoxicity of fumonisin B1, diethylnitrosamine, and catechol on the SNO esophageal cancer cell line. Environ Health Perspect 110(8): 813-815.

22. Alizadeh AM, Rohandel G, Roudbarmohammadi S, Roudbary M, Sohanaki H, et al. (2012) Fumonisin B1 contamination of cereals and risk of esophageal cancer in a high risk area in north eastern Iran. Asian Pac J Cancer Prev 13(6): 2625-2628.

23. RodrÃ guez Amaya DB, Sabino M (2002) Mycotoxin research in Brazil: the last decade in review. Brazilian J Microbiol 33: 1-11.

24. Kumar P, Mahato DK, Kamle M, Mohanta TK, Kang SG (2017) Aflatoxins: A Global Concern for Food Safety, Human Health and Their Management. Front Microbiol 7: 2170.

25. Mohsenzadeh M, Hedayati N, Riahi Zanjani B, Karimi G (2016) Immunosuppression following dietary aflatoxin B1 exposure: a review of the existing evidence. Toxin Rev 35(3-4): 1-7.

26. IARC (1993) International agency for research on cancer, monographs on the evaluation of carcinogenic risks to humans, some naturally occurring substances: Food items and constituents, heterocyclic aromatic amines and mycotoxins, p. 489-521.

27. Diekman M, Green M (1992) Mycotoxins and reproduction in domestic livestock. J Anim Sci 70(5): 1615-1627.

28. Chang K, Kurtz HJ, Mirocha CJ (1979) Effects of the mycotoxin zearalenone on swine reproduction. Am J Vet Res 40(9): 1260-1267.

29. Benzoni E, Minervini F, Giannoccaro A, Fornelli F, Vigo D (2008) Influence of in vitro exposure to mycotoxin zearalenone and its derivatives on swine sperm quality. Reprod Toxicol 25(4): 461-467.

30. Bonnet MS, Roux J, Mounien L, Dallaporta M, Troadec JD (2012) Advances in deoxynivalenol toxicity mechanisms: the brain as a target. Toxins (Basel) 4(11): 1120-1138.

31. Sobrova P, Adam V, Vasatkova A, Beklova M, Zeman L, et al. (2010) Deoxynivalenol and its toxicity. Interdiscip Toxicol 3(3): 94-99.

32. Rahmani A, Jinap S, Soleimany F (2009) Qualitative and Quantitative Analysis of Mycotoxins. Comprehensive Reviews in Food Science and Food Safety 8(3): 202-251.

33. Shanakhat H, Sorrentino A, Raiola A, Romano A, Cavella S, et al. (2018) Current methods for mycotoxins analysis and innovative strategies for their reduction in cereals: an overview. J Sci Food Agric 98(11): 40034013.

34. Jia B, Wang W, Ni XZ, Chu X, Yoon SC, et al. (2020) Detection of mycotoxins and toxigenic fungi in cereal grains using vibrational spectroscopic techniques: a review. World Mycotoxin Journal 13(2): 163-178.

35. Berardo N, Pisacane V, Battilani P, Scandolara A, Pietri A, et al. (2005) Rapid Detection of Kernel Rots and Mycotoxins in Maize by NearInfrared Reflectance Spectroscopy. Journal of Agricultural and Food Chemistry 53(21): 8128-8134.

36. (2020) Plataforma Olimpo.

37. Fandohan P, Hell K, Marasas WFO, Wingfield M (2003) Infection of maize by Fusarium species contamination with fumonisin in Africa. African Journal of Biotechnology 2(12): 571-579.

38. Doohan FM, Brennan J, Cooke BM (2003) Influence of Climatic Factors on Fusarium Species Pathogenic to Cereals. European Journal of Plant Pathology 109(7): 755-768.

39. Hirooka EY, Yamaguchi MM, Aoyama S, Sugiura Y, Ueno Y (1996) The natural occurrence of fumonisins in Brazilian corn kernels. Food Addit Contam 13(2): 173-183.

40. Mallmann C, Santurio J, Almeida C, Dilkin P (2000) Fumonisin B1 in cereals and feeds from southern Brazil. Arq Inst Biol 68(1): 41-45. 
41. Oliveira MS, Rocha A, Sulyok M, Krska R, Mallmann CA (2017) Natural mycotoxin contamination of maize (Zea mays L.) in the South region of Brazil. Food Control 73: 127-132.

42. Orsi R, Corrêa B, Possi C, Schammass EA, Nogueira J, et al. (2000) Mycoflora and occurrence of fumonisins in freshly harvested and stored hybrid maize. Journal of Stored Products Research 36(1): 75-87.

43. Sabino M, Prado G, Inomata E, Pedroso M, Garcia R (1989) Natural occurrence of aflatoxins and zearalenone in maize in Brazil. Part II. Food Addit Contam 6(3): 327-331.

44. Sekiyama BL, Ribeiro AB, Machinski PA, Machinski Junior M (2005) Aflatoxins, ochratoxin A and zearalenone in maize-based food products. Brazilian J Microbiol 36: 289-294.

45. Rocha LO, Nakai VK, Braghini R, Reis TA, Kobashigawa E, et al. (2009) Mycoflora and co-occurrence of fumonisins and aflatoxins in freshly harvested corn in different regions of Brazil. Int J Mol Sci 10(11): 50905103.

46. de Lourdes Mendes de Souza M, Sulyok M, Freitas-Silva O, Costa SS, Brabet C, et al. (2013) Cooccurrence of mycotoxins in maize and poultry feeds from Brazil by liquid chromatography/tandem mass spectrometry. Scientific World Journal 2013: 427369.

47. Kebede H, Abbas HK, Fisher DK, Bellaloui N (2012) Relationship between aflatoxin contamination and physiological responses of corn plants under drought and heat stress. Toxins (Basel) 4(11): 1385-1403.

48. Milanez T, Valente Soares L, Baptista G (2006) Occurrence of trichothecene mycotoxins in Brazilian corn-based food products. Food Control 17(4): 293-298.
49. Mallmann CA, Dilkin P, Mallmann AO (2015) Micotoxinas e micotoxicoses em suínos: situação atual no Brasil. In: Avanços em sanidade, produção e reprodução de suínos. (1 $1^{\text {st }}$ Ed.) Porto Alegre: Federal University of Rio Grande do Sul, Pork Sector, Brazil, pp.221-237.

50. Mallmann C, Dilkin P, Mallmann A, Oliveira M, Coloma Z, et al. (2017) Prevalence and levels of deoxynivalenol and zearalenone in commercial barley and wheat grain produced in Southern Brazil: an eight-year (2008 to 2015) summary. Tropical Plant Pathology 42: 146-152.

51. Geraldo MRF, Tessmann DJ, Kemmelmeier C (2006) Production of mycotoxins by Fusarium graminearum isolated from small cereals (wheat, triticale and barley) affected with scab disease in Southern Brazil. Brazilian J Microbiol 37: 58-63.

52. Salay E, Mercadante A (2002) Mycotoxins in Brazilian corn for animal feed: Occurrence and incentives for the private sector to control the level of contamination. Food Control 13(2): 87-92.

53. Teixeira LC, Montiani Ferreira F, Locatelli Dittrich R, Santin E, Alberton GC (2011) Effects of zearalenone in prepubertal gilts. Pesquisa Veterinária Brasileira 31(8): 656-662.

54. Kuiper Goodman T, Scott PM, Watanabe H (1987) Risk assessment of the mycotoxin zearalenone. Regul Toxicol Pharmacol 7(3): 253-306. 